\title{
Phytoestrogens and their Potential Roles in Prostate Cancer Prevention and Treatment
}

\author{
Swapna Kolukula ${ }^{1,2}$ and Robert J. Anderson ${ }^{1,2 *}$ \\ ${ }^{1}$ Section of Endocrinology, Veterans Affairs Medical Center, VA-Nebraska Western lowa Health Care System \\ ${ }^{2}$ Division of Endocrinology, Department of Medicine, Creighton University School of Medicine
}

\begin{abstract}
Phytoestrogens are hormonally active compounds present in plant foods that are being studied extensively for their potential roles in hormonally-sensitive neoplasms such as prostate cancer. We postulate that the evidence for a protective role of phytoestrogens is not conclusive enough for a general recommendation for their use as dietary supplements, but phytoestrogens can be considered for therapeutic use in prostate cancer patients under certain circumstances. A literature review was performed to study the evidence regarding the chemopreventive role of phytoestrogens in healthy men, the protective role in early prostate cancer, and a possible therapeutic role in advanced prostate cancer patients. Dietary supplementation with phytoestrogens for chemoprevention of prostate cancer is still a debatable subject. Numerous pre-clinical in vitro studies have been promising, and novel molecular mechanisms of action for phytoestrogens continue to be identified. However, human clinical trials including studies done on prostate biomarkers and on the effects of phytoestrogens on steroid hormones are complicated by the possibility of local paracrine effects in prostatic tissue by phytoestrogens that are steroid-like in structure. Their interaction with multiple enzymes represents a paradigm for the complexity of phytoestrogen effects and a window into a potential reason that study results are inconsistent or difficult to explain. A final outcome of the phytoestrogen effect in the intact human may be difficult to discern because these agents can inhibit or induce enzymes, destroy cancer cells, yet will have intrinsic estrogenic effects themselves. Larger multi-center, multi-national, randomized controlled trials are needed before definitive recommendations can be made on the usefulness of phytoestrogens for chemoprevention and therapy for prostate cancer. However, combinations of phytoestrogens with radiation therapy and other antioxidants in advanced or metastatic prostate cancer can be considered because there are limited effective therapy options for this group of patients.
\end{abstract}

\section{Introduction}

Prostate cancer is the most common visceral cancer and the third leading cause of death in the United States [1]. The prevalence of this latent disease is uniform world-wide and microscopic cancerous changes in the prostate gland occur universally as men age [2]. However, the incidence of prostate cancer is lower in the Asian population [3]. The incidence of prostate cancer in Asian immigrants who migrated to United States was comparable to the Western population and positively correlated with the age at immigration. Early life immigrants incidence of prostate cancer was nearly similar to the incidence of prostate cancer in the United States born residents. [4]. The results emphasized that diet and life-style factors were major components of the effects of geographic localization. Hormonally active compounds like phytoestrogens in Asian vegetarian and semivegetarian diets were hypothesized as the possible cause of the lower incidence of hormonally dependent tumors in Asian populations [5]. Phytoestrogens are biologically active phytochemicals with estrogenic and/or anti-estrogenic effects in the human body [6]. They are further classified into isoflavonoids, flavonoids, stilbenes, lignans and others on the basis of their chemical structure [7] See Figure 1. Isoflavone intake in Asian countries is approximately $25-50 \mathrm{mg} /$ day, which is tenfold higher than the intake in Western countries [8]. Phytoestrogens are being studied extensively for their potential roles in hormonallysensitive cancers such as prostate, breast and colon cancers [9]. Most of the evidence thus far on the possible protective role of phytoestrogens is from epidemiologic, observational studies, in vitro and cell culture studies and small, randomized clinical trials with less than 100 patients. To date, the results have been inconsistent with possible benefits in some trials versus no benefits of phytoestrogens on prostate cancer in other trials. To our knowledge, there have been no final reports of large, randomized, controlled trials evaluating the benefits of phytoestrogens in prevention or treatment of prostate cancer. Hence, our goal is to review the current evidence on the potential role of phytoestrogens in prostate cancer. These compounds are of increasing interest to both the general population and to health care providers for cancer prevention and stabilization, given their availability in plant foods and in overthe-counter dietary supplements. We postulate that the evidence for a protective role of phytoestrogens is not conclusive enough for physicians to recommend them routinely as dietary supplements to prostate cancer patients or to men at high risk for prostate cancer, but their use can be considered for therapeutic use in prostate cancer patients under certain circumstances.

Phytoestrogen-rich foods consist mainly of soy products (flavonoids), whole grain products (plant lignans) and red clover (biochanin A, formononetin) [9]. Of all the compounds, isoflavones and lignans are the most studied. Isoflavones have inherent estrogenic

*Corresponding author: Robert J. Anderson, MD, Professor of Medicine Creighton University School of Medicine, Chief, Section of Endocrinology, VANebraska Western lowa Health Care System, 4101 Woolworth Ave. Research 151 Omaha, NE 68105, USA, Tel: 402-995-4312; Fax: 402-977-5624; E-mail: robert. anderson4@va.gov

Received September 21, 2011; Accepted November 06, 2011; Published November 08, 2011

Citation: Kolukula S, Anderson RJ (2011) Phytoestrogens and their Potential Roles in Prostate Cancer Prevention and Treatment. J Cancer Sci Ther S1. doi:10.4172/1948-5956.S1-002

Copyright: (c) 2011 Kolukula S, et al. This is an open-access article distributed under the terms of the Creative Commons Attribution License, which permits unrestricted use, distribution, and reproduction in any medium, provided the original author and source are credited. 


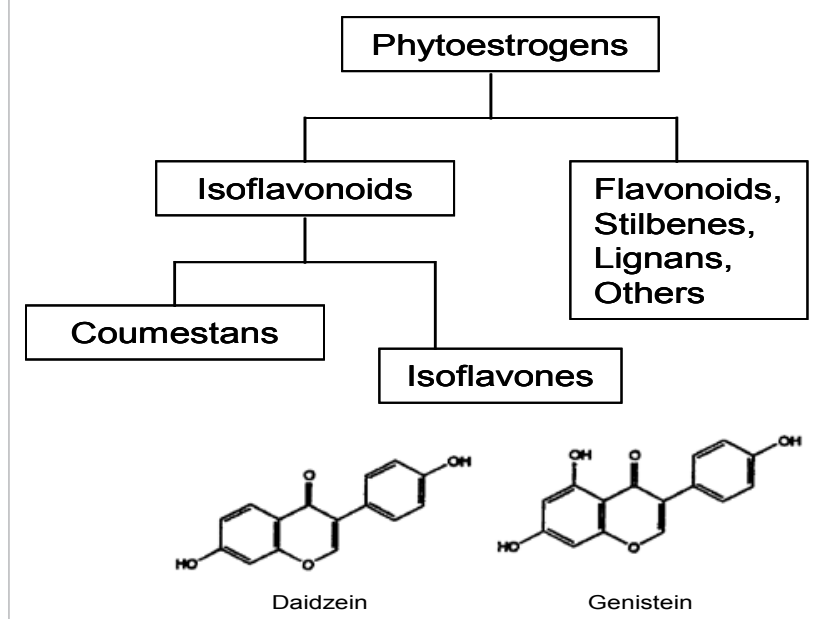

Figure 1: Schematic

of phytoestrogens. Structures of daidzein and genistein are included. Equol (structure not shown), a third active isoflavone, is a metabolite of daidzein.

activity and lignans are converted to weakely estrogenic compounds by the human gut bacteria [9]. The main isoflavones from the diet are genistein, daidzein and glycitein and the most estrogenic phytoestrogens are coumestrol (coumestan), genistein and equol [9]. Equol is the active metabolite of daidzein produced in the upper portion of small gut by intestinal bacteria $[9,10]$. Only $30 \%$ of humans are able to produce equol via the above mechanism and are labeled as daidzein degraders/metabolizers or equol producers [11]. Case control studies done by Akaza et al. [12,13] in Japanese, Korean and American residents revealed a lower prevalence of daidzein degraders in subjects who had prostate cancer when compared with those in the control group, and an overall lower occurrence of daidzein degraders in American residents compared with Asian residents. These findings led to the hypothesis that there was a lower incidence of prostate cancer in daidzein degraders [13]. However, larger multi-ethnic studies by Park et al. and European studies (European Prospective Investigation into Cancer and Nutrition, EPIC trials) failed to show any association between equol production and prostate cancer risk $[14,15]$.

Plant lignans are converted into mammalian lignans (enterodiol and enterolactone) by gut flora [11]. Plasma enterolactone concentration is affected by various lifestyle factors and medicines. Obesity in females, and smoking in both sexes were associated with decreased plasma enterolactone, whereas a diet rich in vegetables, fruits, coffee and wine was associated with elevated enterolactone levels [16]. The importance of alterations in these levels from lignans for prostate cancer is uncertain. A large, multi-center longitudinal, nested case-control study of subjects located in Finland, Norway, and Sweden failed to show any association between high levels of serum enterolactone and decrease risk of developing prostate cancer (cases $=794$, age-matched control group $=2550$, mean follow-up period of 14.2 years) [17].

\section{Epidemiologic and Observational Studies}

A few epidemiologic studies and observational studies raised interest in phytoestrogens as potential protective or treatment avenues for prostate cancer. Early epidemiologic observational and case control studies in Asian countries showed an association between intake of soy products and a decreased incidence of prostate cancer. For example, Sonada et al. [18] performed a hospital-based case-control study evaluating dietary factors in Japan (cases $=140$, age matched hospital control=140) and reported an inverse association between soy products and prostate cancer risk. Similar conclusions were drawn by Lee et al. [19] who performed a population-based case control study in China ( cases $=133$, controls $=265$ ). They reported high soy intake was associated with a significant decreased risk for prostate cancer. Case control studies performed in European and North American nations also showed a reduction in prostate cancer risk with increased soy product consumption. Kolonel et al. [20] conducted a case-control study of 1619 cases of prostate cancer and 1618 general population controls in the United States, and reported that increased soy food consumption was inversely associated with prostate carcinoma risk. Jacobson et al. [21] performed a large prospective study in the United States during which they followed 12,365 Seventh-day Adventist American men from California for 16 years and reported that increased consumption of soymilk and isoflavone was associated with decreased risk of prostate cancer. However their food questionnaire did not include other food items rich in isoflavone such as tofu and miso soup. These studies set the stage for various in vitro and in vivo studies to determine potential chemoprotective and treatment roles of phytoestrogens for prostate cancer. Many other epidemiological studies are summarized in various published review articles [5,22-24].

Adlercreutz [11] hypothesized that whole grain intake rich in lignans is also associated with lower incidence of prostate cancer. $\mathrm{He}$ reported that a rural Finnish population had a lower incidence of prostate cancer even though their soy intake was not as high as the Asian population. He also measured serum levels of lignans which were higher in rural Finnish adults and postulated that high lignan intake was protective against prostate cancer in this population. A case-control study by Hedelin et al. [25] in a Swedish population $(n=2629)$ showed that the group with a high intake of food rich in phytoestrogens was associated with a decreased risk of both early and advanced prostate cancer. However, a similar association was not seen when individual phytoestrogens - total lignans alone or total isoflavonoid compounds and risk of prostate cancer were studied. They also measured enterolactone levels in a subset of the study population (cases $=218$, controls $=221$ ). They reported that intermediate serum enterolactone levels were associated with a reduction in prostate cancer risk and they concluded there was an inverse but non-linear association between serum enterolactone levels and prostate cancer risk [25] However, a case-control study by Heald et al. [26] in subjects with benign prostatic hyperplasia (433 cases and 483 controls) in Scotland showed significant protective effect of soy products consumption against prostate cancer, but reported that there was no correlation between serum concentrations of isoflavone and prostate cancer risk.

\section{Studies Addressing Phytoestrogen Mechanisms of Action}

Multi-targeted mechanisms of action for phytoestrogens and their metabolites have been identified and proposed. Recent articles reviewed by Taylor et al. [27], Banerjee et al. [28] and de Souza et al. [29] summarized various in vivo, in vitro and human studies on mechanisms of action of genistein in relation to cancer. The identified targets are summarized in the following section under four categories: Receptor and molecular targets, enzymes and metabolic pathways, cytotoxic effects and anti-metastatic effects.

Receptor and molecular targets: Isoflavones have affinity for the estrogen receptor beta with antagonistic and partial agonistic actions 
[30]. Genistein down-regulates androgen receptor by decreasing the chaperone activity of Hsp 90 (Heat shock protein) which is required for stabilization of the receptor [31]. Pihlajamaa et al. [32] recently reported that genistein is a tissue-specific androgen receptor modulator. Genistein $(10 \mathrm{mg} / \mathrm{kg})$ was fed to both intact male mice and castrated mice for 5 days. It was noted that genistein had an anti-androgenic effect on testis, prostate and brain in intact male mice, whereas androgenic effect was observed on prostate and brain tissues of the castrated mice. Davis et al. [33] reported a ligand-dependent difference in transcriptional regulation of prostate specific antigen (PSA) by genistein. It was shown that genistein decreased androgen mediated transcriptional activation of PSA. However dose-dependent effect was noted on estrogen mediated PSA expression. Low concentrations of genistein stimulated PSA expression and high concentrations inhibited the estrogen mediated PSA expression. Genistein also increased Sex Hormone Binding Globulin (SHBG) and, thus, decreased the bioavailability of free androgens and estrogens in addition to its independent effects on androgen and estrogen signaling pathways [34]. Hiroven et al. [35] showed that equol stimulated transcriptional activity of ERR Gamma (Estrogen related receptor) in prostate cancer PC3 cell lines causing growth inhibition. Several effects of isoflavones upon molecular targets were discussed in a comprehensive review by Banerjee et al. [28] and de Souza et al. [29]. Some of these effects included inhibition of protein tyrosine kinase, inhibition of DNA topoisomerase I/II, induction of PTEN (Phosphatase and tensin homolog) expression which is a tumor suppressor gene. Molinie and Georgel [36] mentioned epigenetic targets of genistein in addition to genetic molecular targets which had subsequent effects on gene expression and biological pathways associated with prostate cancer. The mechanism of epigenetic regulation consisted of DNA and histone modifications that generated additional targets for regulatory cofactors. Genistein effects on DNA methylation (DNMT), histone post translational modifications and possibly on chromatin structure and remodeling have been described [36].

\section{Enzymes and metabolic pathways}

Genistein and daidzein can inhibit and induce various enzymes involved in sex steroid metabolism [37-42]. They inhibit steroid metabolizing enzymes such as 5-alpha reductase [29], aromatase [7,39] and $17-\beta$ hydroxysteroid dehydrogenase Type 1 [37]. Figure 2 illustrates possible metabolic pathways for the production and metabolism of sex steroids in the human prostate. Isoflavones are also thought to be both stimulators and inhibitors of SULT (Sulfotransferases) in a dose dependent fashion. Nishiyama et al. [44] reported that daidzein and genistein are predominantly sulfated by SULT1A1 and SULT1E1, respectively in humans and inhibit the sulfation of the endogenous substrate, beta-estradiol. Harris et al. [41] demonstrated that equol, genistein and daidzein inhibited human SULT1E1 in that order of potency. Human SULT1A1, another sulfotransferase involved in the sulfation of estrogens, also uses daidzein as a substrate, and is inhibited by both daidzein and genistein at similar concentrations [38]

\section{Cytotoxic effects}

These include caspase mediated apoptosis, inhibition of VEGF (Vascular Endothelial Growth Factor), inhibition of TGF beta (Transforming Growth Factor) and inhibition of activation of transcription factors like NF- $\mathrm{kB}$ which play an important role in cell growth, differentiation, proliferation and apoptosis [29]. Fotsis et al. [45] reported suppression of angiogenesis by phytoestrogens. Inflammatory and steroid pathway modulation via inhibition of prostaglandin synthesis in patients treated with soy supplements has also been identified [46]. El Touny et al. [47] reported a novel target for anti-proliferative effect by genistein in a transgenic adenocarcinoma mouse prostate model (TRAMP).

\section{Anti-metastatic effects}

Lakshman et al. [48] described a murine model that elucidated the in vitro anti-metastatic effects of genistein by inhibition of the focal adhesion kinase (FAK), p38 mitogen-activated protein kinase (MAPK) and heat shock protein 27 (HSP27) pathways. These pathways aid in

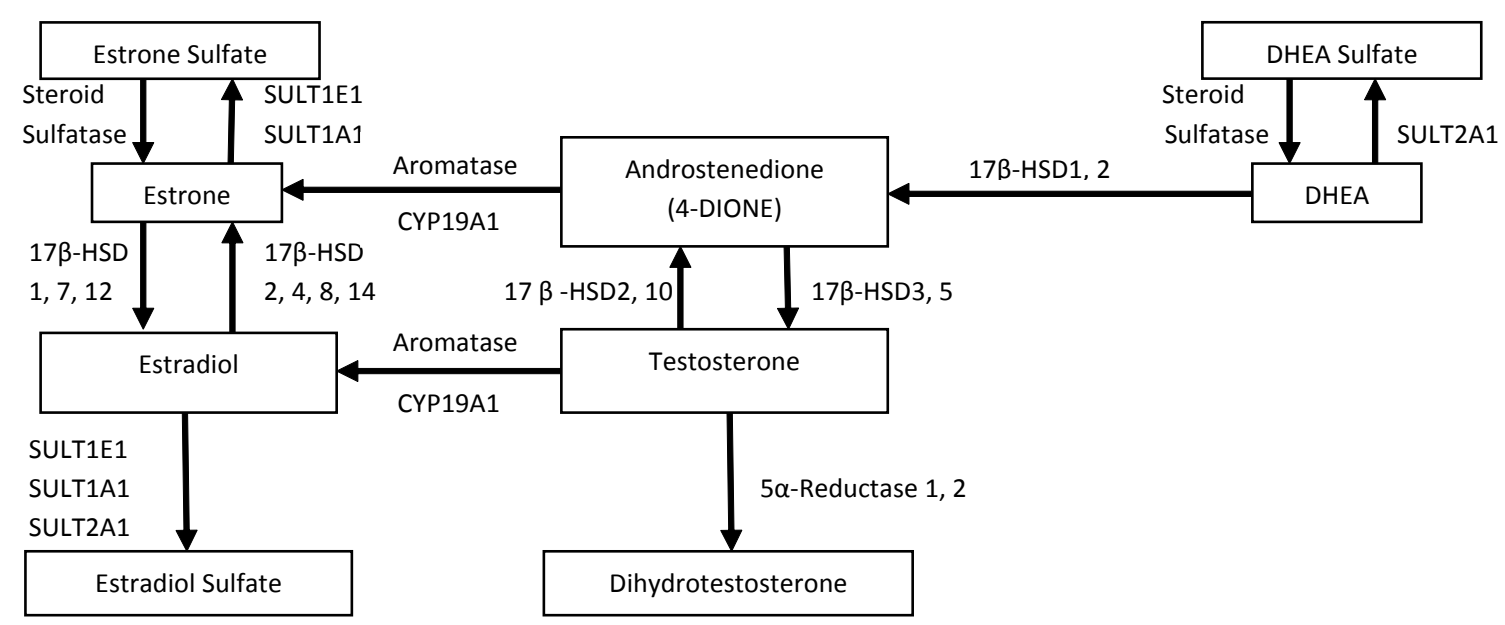

Figure 2: Schematic diagram of potential metabolic and biosynthetic pathways for sex steroids in the human prostate. Abbreviations include: DHEA, dehydroepiandrosterone; HSD, hydroxysteroid dehydrogenase with numbers indicating the various isozymes involved; SULT, sulfotransferase; CYP, cytochrome P450; CYP19A1 indicates Aromatase. SULT1A1 has been identified in prostatic tissue. SULT1E1 is found in both normal prostate, and benign prostatic hyperplastic tissue and is decreased in prostate cancer cells. The isoflavone daidzein serves as a substrate for SULT1A1, and at higher concentrations, it will inhibit SULT1A1 activity. Genistein is a substrate for SULT1E1, and at higher concentrations, it will inhibit both SULT1E1 and SULT1A1. See text for details. SULT2A1 has not yet been identified in prostatic tissue [43]. The figure is adapted from references 41 and 42. 
cell detachment and cell invasion. The study reported that genistein caused a compensatory increase in promotility agents such as FAK, p38 MAPK, HSP27 due to its antimotility effect on prostate cancer cells [48]. Human studies performed by Xu et al. [49] reported that genistein blocks MEK4 (Mitogen-activated protein kinase 4) in addition to p38 mitogen and decreases MMP-2 (Matrix Metalloproteinase-2). MMP-2 is elevated in invasive prostate cancer and is recognized to potentiate cell invasion and metastases [50,51].

\section{Animal models}

The study of the effects of isoflavones in vitro prompted further research using animal models. For example, Zhou et al. [52] conducted a study in which, 8 week-old severe combined immune-deficient mice were subcutaneously inoculated with androgen-responsive prostate cancer cells (LNCaP). The mice were later randomized to six different experimental diets. One was control diet and other five had two protein sources, casein vs. soy and three different strengths of soy concentrate. The mice fed with the higher concentration of soy products had a statistically significant reduction in prostatic tumor volume compared with mice fed with the control diet. Histopathological examination of the tumor tissue from the soy-fed mice showed reduced tumor cell proliferation, increased tumor cell apoptosis and reduced tumor angiogenesis. Fritz et al. [53] studied the effects of isoflavone (Genistein) on both Estrogen receptor (ER) and Androgen receptor (AR) expression in rat prostate. Seven-week old female Sprague-Dawley rats were fed with 0,250 or $1000 \mathrm{mg} / \mathrm{kg}$ of genistein enriched diet pre and post-natally. Their male offspring were fed 0,25 or $250 \mathrm{mg} / \mathrm{kg}$ genistein diet from conception to day 70. In male offspring fed with the $250 \mathrm{mg} /$ $\mathrm{kg}$ genistein enriched diet, statistically significant reductions in AR, ER alpha and ER beta mRNA expression were observed when compared with the controls. Also, dose dependent suppression of AR and ER was noted when young adult male rats were fed with 0,250 or $1000 \mathrm{mg} / \mathrm{kg}$ genistein enriched diet for 2 weeks.

\section{Human studies}

Hong et al. [54] studied phytoestrogen levels in Benign Prostatic Hyperplasia (BPH) tissue in Korean men and reported significantly higher tissue levels of genistein in small volume BPH compared with large volume $\mathrm{BPH}$ prostates. A similar study done in Western men by Brossner et al. [55] in both small and large volume BPH and prostate carcinoma tissues revealed lower genistein levels in prostate carcinoma and high volume BPH. Enterolactone tissue levels revealed no statistically significant differences in 3 groups. Hence they concluded a comparable potential effective role of genistein locally within the prostate gland in both Asian and Western men.

\section{Human Trials of Phytoestrogens and Prostate Health and Disease}

Studies performed on healthy male subjects, ages 20 to 80 years, did not reveal any protective effect of phytoestrogens on prostate cancer risk. The Soy Isoflavone Prevention Trial (SIP), a randomized, double-blinded, placebo-controlled, dietary intervention study, was done to evaluate the effects of soy isoflavones on markers of colon cancer [56]. Adams et al. [56] did an ancillary study to the SIP trial and reported that one year dietary supplementation with $83 \mathrm{mg}$ per day of isoflavone did not alter serum PSA concentration in 112 healthy men aged 50-80 yrs. In line with the result from the SIP trial, Ward and Kuhnle [57] reviewed another subset population $(n=11,607$ males with ages ranging from 45 to 75 years) using the EPIC Norfolk randomized clinical trial, which studied phytoestrogen consumption and its association with breast, prostate and colorectal cancer. They concluded that although prostate cancer was positively associated with enterolignan and equol intake in the EPIC Norfolk study, the association became non-significant when adjusted for dairy intake. Both these studies conveyed the lack of a protective role of isoflavone on prostate cancer risk in healthy men. Dillingham et al. [58] studied the effect of soy protein isolates on reproductive hormones in young men 20 to 40 years of age. They randomized 35 healthy men to receive either milk protein isolate or low-isoflavone soy protein isolate (1.64 \pm $0.19 \mathrm{mg}$ isoflavones/day) or high-isoflavone soy proteins isolate $(61.7 \pm$ $7.35 \mathrm{mg}$ isoflavones/day) for 57 days in a randomized crossover design. Periodic serum measurements revealed a statistically significant decrease in Dihydrotestosterone (DHT) and DHT/testosterone, and testosterone with both low and high isoflavone supplementation. Effects of treatment on serum concentrations of free testosterone, androstenedione, DHEA (Dehydroepiandrosterone), SHBG, LH (Luteinizing Hormone), or FSH (Follicle Stimulating Hormone) were not significant. However, a few studies conducted in subjects with high baseline PSA revealed a decrease in the PSA level while on soy supplementation [63]. Data from a randomized crossover study performed by Maskarinec et al. [59] in 23 healthy men with a mean age of 58 years revealed a $14 \%$ statistically significant decline in PSA with no change in testosterone level when the subjects were given a high soy diet compared with a low soy diet. A randomized controlled trial done by Ide et al. [60] in Japenese men $(n=85)$ with a median age of 73 years showed that PSA levels significantly decreased in the supplement treated group (isoflavones $40 \mathrm{mg}$ plus curcumin $100 \mathrm{mg}$ daily for 6 months) only in those subjects with a baseline PSA level greater than $10 \mathrm{ng} / \mathrm{ml}$, with no prostate cancer.

For studies done in patients with early prostate cancer, the role of phytoestrogens was not protective or therapeutic. Kumar et al. [61] did a small $(n=59)$, randomized placebo-controlled, doubleblinded interventional trial to see the effect of isoflavone $60 \mathrm{mg}$ supplementation for a 12 -week period in men aged 45-85 yrs with early prostate cancer. They noted no change or a decrease in the serum PSA and free testosterone in isoflavone-treated group when compared with placebo-treated patients. However, the results did not achieve statistical significance. Similar results were found in another randomized control trial. A double-blinded, placebo-controlled, randomized study was conducted by White et al. [62] in patients $(n=53)$ with low volume prostate cancer who were randomized to receive high dose of aglycone-rich soy supplement containing $450 \mathrm{mg}$ genistein, $300 \mathrm{mg}$ daidzein, and other isoflavones daily for 6 months. Serum isoflavone levels and PSA levels were measured at baseline, 3 months and 6 months. Even though serum isoflavone levels were elevated in response to the dietary supplementation, serum PSA concentrations did not change significantly. Interestingly, no change in serum equol was noted in study or placebo group. It is biologically plausible that all of the study participants were not daidzein degraders. Another interesting study done on men at high risk for prostate cancer or with low-grade prostate cancer $(n=58)$, evaluated soy supplementation effect on prostate biomarkers. The subjects were randomly assigned to consume one of 3 protein isolates for 6 months: Soy protein (107 $\mathrm{mg}$ isoflavones/day), alcohol-washed soy protein (less than $6 \mathrm{mg}$ isoflavones/day), or milk protein (no isoflavone). The following prostate tissue biomarkers were assessed in prostate biopsy cores at baseline and study completion: proliferating cell nuclear antigen (PCNA), epidermal growth factor receptor, B-cell non-Hodgkin lymphoma-2 (Bcl-2), and Bcl-2-associated X protein (Bax). The authors concluded 
that 6-months of soy protein consumption did not alter prostate tissue biomarkers and alcohol washed soy consumption (low levels of soy) exerted mixed effects. Less prostate cancer was detected after 6 months of soy consumption regardless of isoflavone content when compared with the milk protein group [63]. In an additional study done on the same population sample, urinary estradiol and urinary 2-hydroxyestrogens:16 alpha-hydroxyestrone were measured at 0 , 3 and 6 months of the above supplementation. The baseline levels of urinary estrogen metabolites in men with prostate cancer were lower compared with controls. However, during the intervention period in this study, higher levels of urinary estradiol were noted in both soy groups when compared with the milk protein group, supporting a potential effect of soy products on endogenous estrogen metabolism to increase their levels to have a beneficial effect on prostate cancer [64].

Studies done with advanced prostate cancer patients did not show promising results. Gardner et al. [65] studied serum and prostatic tissue concentrations of soy components (genistein and daidzein) after randomization of 19 men with prostate cancer who received soy supplementation (isoflavone $82 \mathrm{mg} /$ day) vs. placebo for a 2 week period prior to radical prostatectomy. They reported an approximate 6 -fold increased concentration in prostatic tissue isoflavones compared with serum levels. The tissue:serum ratio was significantly lower for genistein (4-fold) than for daidzein (10-fold). The study supported the hypothesis that prostatic tissue might have ability to concentrate dietary soy products to anti-carcinogenic levels that have been reported with in vitro studies. In line with the previous study, Rannikko et al. $[66,67]$ conducted a randomized, prospective study to investigate the bioavailability of oral phytoestrogens locally within the prostatic tissue. Forty men with prostate cancer were randomized to receive $240 \mathrm{mg}$ of clover phytoestrogens or placebo daily for a 2 week period prior to radical prostatectomy. Phytoestrogens genistein, daidzein and equol were measured in the plasma and prostate tissue. At baseline all subjects had low plasma and prostatic tissue phytoestrogens and only $35 \%$ had detectable plasma concentration of equol. At the conclusion of the study, they noted that the prostate tissue had the ability to concentrate phytoestrogens locally two-fold higher than the plasma level even in patients who did not receive the supplementation. The plasma levels of other phytoestrogens including equol were significantly higher in patients who received the clover supplement. In another study done on same population sample, it was also found that oral phyotestrogen supplementation treatment interfered with the hypothalamicpituitary- testicular axis in prostate cancer patients by inducing testicular resistance to Luteinizing Hormone and causing compensated hypogonadism [67]. Dalais et al. [68] conducted a randomized, doubleblinded, placebo- controlled study in advanced prostate cancer patients $(n=28)$. Subjects were randomized to three groups: heat-treated (HT) soy $(n=8)$, HT soy plus linseed $(n=10)$, and wheat $(n=8)$ for 22 to 27 days. There was statistically significant decrease in the PSA level and free/total PSA ratio in subjects who were randomized to the heat treated soy grits group $(117 \mathrm{mg}$ ) when compared with the subjects who received soy plus linseed or with those who received wheat. However, no alterations in testosterone and dihydrotestosterone levels were reported. Because subjects had advanced prostate cancer, the tumor may have been in a hormone-independent stage and, thus, would not be affected by the ambient androgens levels regardless of the phytoestrogen intervention. However, an increase in SHBG with no increase in free PSA was noted in the heat-treated soy group. Subsequent increased binding of free testosterone to SHBG could contribute to decreased testosterone effect.
There was also no decrease in the PSA level in the group that received soy plus linseed (a lignan), a finding that raised the possibility that linseed inhibited the protective effect of phytoestrogens in soy, and that linseed alone lacked a protective effect against prostate cancer.

Studies conducted in patients with biochemical relapse of prostate cancer showed a decline in PSA level and an increase in doubling time of PSA while on soy supplementation, supporting the anti-proliferative effects of isoflavones on prostate cancer cells. Pendleton et al. [69] performed a one year non-randomized phase II interventional study with soy milk supplementation containing approximately $141 \mathrm{mg} /$ day of isoflavonoid. The study patients had rising PSA levels statuspost local therapy including radiation therapy, radical prostatectomy, androgen deprivation therapy either alone or in combination. Serum PSA, testosterone, lipids, isoflavone levels (genistein, daidzein, and equol), and quality of life (QOL) were measured periodically. Mixed regression model analyses showed a statistically significant decline in the PSA rise from an estimated 56\% per year prior to study enrollment to $20 \%$ per year for the one year study period. There was a statistically significant decrease in free testosterone only and not in the total testosterone. No significant difference in QOL pre-therapy and during therapy was observed. Another study was done in a cohort of North American men $(n=29)$ with rising PSA levels, post-radical radiation therapy for prostate cancer with no other evidence of recurrent clinical disease. After 6 months of daily supplementation with soy beverage, there was a declining PSA trend or a more than 2-fold prolongation of PSA doubling time in $41 \%$ of the subjects [70]. Schroder et al. [71] conducted a double-blinded, randomized, placebo-controlled crossover study in men with prostate cancer after treatment with radical prostatectomy or radiotherapy that had rising PSA levels. All subjects received antioxidants and vitamins and were randomized to receive daily soy isoflavone concentration of $62.5 \mathrm{mg}$ versus placebo for a 10-week period, and then a crossover for 10 weeks after a 4 -week wash out period. They reported a statistically significant decrease in the PSA slope and a projected 2.6-fold increase in PSA doubling time in the group that received the soy supplements. The changes in serum total PSA were identical in both groups and were not significantly different. The authors concluded that soy supplementation delays PSA progression in men with prostate cancer who have biochemical relapse with rising PSA status post therapy.

Only a few in vitro and clinical studies looked into possible synergistic effects of soy supplementation with other antioxidants and also with concurrent radiation therapy. An in vitro study conducted by Kumar et al. [72] described a synergistic effect from a combination of three phytoestrogens that included genistein, biochanin, and quercetin. This combination inhibited the growth of androgen-responsive prostate cancer cells (LNCaP) as well as androgen-independent metastatic prostate cancer cells (DU-145) and PC-3 prostate cancer cells by both estrogen dependent and independent pathways and by stimulation of caspase- 3 activity. A phase two clinical trial by Vaishampayan et al. [73] investigated the efficacy of lycopene alone or in combination with soy isoflavones on serum PSA in men with prostate cancer who had rising serum PSA status- post local therapy or while on hormone therapy $(\mathrm{n}=71)$. The authors concluded that there was no decline in serum PSA level in either group and that there was no additive effect with both compounds. However, stabilization of serum PSA level was noted in most of the patients in the study. Hillman et al. [74] investigated the synergistic effect of genistein and radiation therapy for localized prostate cancer. It was shown in vitro that genistein sensitized prostate cancer cells to radiation effects and thus augmented inhibition of DNA 
synthesis and cell division and growth. On a similar note, Rafful et al. [75] concluded that genistein inhibited radiation-induced activation of the survival pathway (NF-Kappa B) and caused apoptosis and G2/M cell cycle arrest leading to cell death. Ahmad et al. [76] did a pilot study to investigate the effects of soy isoflavone supplementation on acute and subacute toxicity of external beam radiation therapy in patients with localized prostate cancer. Patients $(n=42)$ were randomized to receive $200 \mathrm{mg}$ soy isoflavone vs placebo for 6 months upon initiation of radiation therapy. Self-administered quality of life questionnaires were done at 3 months and 6 months. It was noticed that the patients randomized to soy isoflavone group had lower urinary, intestinal and sexual adverse effects. The authors postulated a possible protective role of isoflavones from adverse effects of radiation therapy for prostate cancer. They did not provide follow-up data on any differences in the course of the prostate cancer after the 6 month treatment.

Other pre-clinical studies have supported the basis for clinical trials that test combination therapies of phytoestrogens and selected compounds. Vitamin D is being extensively evaluated for its role as a chemoprotective agent. A recent review article by Krishnan et al. [77] provides a summary of the work done on the synergistic effect of calcitriol and genistein in prostate cancer cells. In Vitro studies showed that genistein inhibits CYP24 enzyme activity that metabolizes calcitriol and also amplifies up-regulation of Vitamin D Receptor (VDR). The increase in the bioavailability of the calcitriol along with increased VDR levels sensitized the prostatic cells to the growth inhibitory effect of calcitriol [77]. Kumi-Diaka et al. [78] investigated the effects of genistein-selenium combination on chemosensitivity and matrix metalloproteinase-2 (MMP-2) expression levels in PC3 (hormoneindependent) and LNCaP (hormone-dependent) prostate cancer cells and reported that genistein alone, selenium alone and the combination of both agents showed growth inhibition by apoptosis induction and by decreased MMP 2 expression in a time- and dose- dependent fashion. The combination regimen was significantly superior to either agent alone. A similar synergistic effect from a combination of selenium and genistein on prostate cancer cells in vitro was reported by Zhao et al. [79]. Finally, Chang et al. [80] investigated the combination regimen of terazosin and genistein in DU-145 cells, a metastatic, androgenindependent prostate cancer cell line. The results showed that the combination regimen at a lower and non-toxic anticancer dosage range was more effective than either agent alone in inhibiting cell growth, VEGF (Vascular Endothelial Growth Factor) expression and induction of apoptosis.

There are several ongoing current trials designed to address the questions of effective phytoestrogen doses, length of treatment, and combinations with other agents, based, in part, on concerns that previous trials were not long enough to document potential effects.

\begin{tabular}{|c|c|c|c|c|}
\hline Study Number & Brief Study Title & $\begin{array}{l}\text { Study Design and Study } \\
\text { Period }\end{array}$ & Study status & Primary outcomes \\
\hline $\begin{array}{l}\text { Cancer } \\
\text { Prevention Study } \\
\text { NCT01174953 }\end{array}$ & $\begin{array}{l}\text { High risk prostate cancer prevention study. } \\
\text { Study of molecular effects of finasteride plus dietary soy } \\
\text { supplementation in patients at high risk for the development } \\
\text { of prostate cancer and creation of large database with health } \\
\text { information. }\end{array}$ & $\begin{array}{l}\text { Non-randomized open label } \\
\text { interventional study (July } \\
2010 \text { - Sep 2012) }\end{array}$ & $\begin{array}{l}\text { Active, not } \\
\text { recruiting }\end{array}$ & $\begin{array}{l}\text { Identify biomarkers to predict patient } \\
\text { at risk for prostate cancer and benefit } \\
\text { from preventive strategies }\end{array}$ \\
\hline $\begin{array}{l}\text { Single agent } \\
\text { treatment study } \\
\text { NCT01036321 }\end{array}$ & $\begin{array}{l}\text { Phase II clinical trial of purified isoflavones in prostate } \\
\text { cancer: comparing safety, effectiveness and mechanism of } \\
\text { action between African American and Caucasian men }\end{array}$ & $\begin{array}{l}\text { Randomized double } \\
\text { blinded phase II } \\
\text { interventional study (Dec } \\
2009 \text { - Jan 2015) }\end{array}$ & Recruiting & $\begin{array}{l}\text { Assess efficacy of isoflavones } \\
(40 \mathrm{mg} / \text { day }) \text { versus placebo } \\
\text { and evaluate side effects from } \\
\text { supplementation }\end{array}$ \\
\hline $\begin{array}{l}\text { Single agent } \\
\text { treatment study } \\
\text { NCT01126879 }\end{array}$ & Genistein in treating patients with prostate cancer & $\begin{array}{l}\text { Randomized double } \\
\text { blinded phase II } \\
\text { interventional study (May } \\
\text { 2010- May 2014) }\end{array}$ & $\begin{array}{l}\text { Recruiting. } \\
\text { Estimated } \\
\text { enrollment } 36 .\end{array}$ & $\begin{array}{l}\text { Determine if genistein decreases the } \\
\text { number of circulating prostate cells } \\
\text { in the blood }\end{array}$ \\
\hline $\begin{array}{l}\text { Early treatment } \\
\text { combination study } \\
\text { NCT01325311 }\end{array}$ & $\begin{array}{l}\text { Study of cholecalciferol and daily genistein (G-2535) versus } \\
\text { placebo in men with early stage prostate cancer }\end{array}$ & $\begin{array}{l}\text { Randomized double } \\
\text { blinded phase II } \\
\text { interventional study (May } \\
\text { 2011- May 2013) }\end{array}$ & $\begin{array}{l}\text { Not yet } \\
\text { Recruiting. } \\
\text { Estimated } \\
\text { enrollment } 50 \text {. }\end{array}$ & $\begin{array}{l}\text { Measure prostatic tissue levels } \\
\text { of calcitriol, other cholecalciferol } \\
\text { metabolite levels and all } \\
\text { cholecalciferol metabolite levels in } \\
\text { the plasma. }\end{array}$ \\
\hline $\begin{array}{l}\text { Combination } \\
\text { Study } \\
\text { NCT00499408 }\end{array}$ & $\begin{array}{l}\text { Vitamin D and soy supplements in treating patients with } \\
\text { recurrent prostate cancer }\end{array}$ & $\begin{array}{l}\text { Phase II interventional } \\
\text { study. April 2007- April } \\
2009 \text { (Primary completion } \\
\text { period) }\end{array}$ & Recruiting & $\begin{array}{l}\text { Serum PSA response to Vitamin D } \\
\text { and soy supplements. }\end{array}$ \\
\hline $\begin{array}{l}\text { Combination } \\
\text { Study } \\
\text { NCT00354432 }\end{array}$ & $\begin{array}{l}\text { Soy/isoflavones and venlafaxine in treating hot flashes in } \\
\text { patients receiving hormone therapy for prostate cancer }\end{array}$ & $\begin{array}{l}\text { Phase III randomized } \\
\text { double blinded placebo } \\
\text { controlled interventional } \\
\text { Study. Feb } 2007 \text { - Feb } \\
\text { 2010. (Estimated primary } \\
\text { completion date) }\end{array}$ & $\begin{array}{l}\text { Active, not } \\
\text { recruiting }\end{array}$ & $\begin{array}{l}\text { Assess the effect of soy protein/ } \\
\text { isoflavones and venlafaxine on the } \\
\text { hot flash symptom severity score } \\
\text { in patients undergoing hormonal } \\
\text { manipulation for treatment of } \\
\text { prostate cancer. }\end{array}$ \\
\hline $\begin{array}{l}\text { Combination study } \\
\text { NCT01009736 }\end{array}$ & $\begin{array}{l}\text { Effects of tomato-soy juice on biomarkers in patients with } \\
\text { prostate cancer undergoing prostatectomy }\end{array}$ & $\begin{array}{l}\text { Open label phase I-II } \\
\text { interventional study. } \\
\text { Jan } 2008 \text { - Jan } 2009 . \\
\text { (Estimated primary } \\
\text { completion date) }\end{array}$ & Recruiting & $\begin{array}{l}\text { Incidence and severity of toxicity } \\
\text { associated with tomato-soy juice }\end{array}$ \\
\hline \begin{tabular}{|l|} 
Prevention of \\
Recurrence Study \\
NCT00765479
\end{tabular} & $\begin{array}{l}\text { Soy protein in preventing recurrent cancer in patients who } \\
\text { have undergone surgery for stage II prostate cancer }\end{array}$ & $\begin{array}{l}\text { Randomized double } \\
\text { blinded phase II-III } \\
\text { interventional study. } \\
\text { Dec } 2006 \text { - Sep } 2011 . \\
\text { (Estimated primary } \\
\text { completion date) }\end{array}$ & $\begin{array}{l}\text { Recruiting. } \\
\text { Estimated } \\
\text { enrollment } 284 .\end{array}$ & $\begin{array}{l}\text { Two-year PSA failure rate (as a } \\
\text { surrogate for recurrence) and } \\
\text { time to PSA failure }\end{array}$ \\
\hline
\end{tabular}

Table 1: Retrieved from Clinicaltrials.gov, Aug 26, 2011. 
These are summarized in Table 1 . Recently completed trial results have not been published yet.

\section{Discussion}

Based on previous epidemiologic studies, pre-clinical studies and clinical trials, phytoestrogens may have a range of applications in the prevention and treatment of prostate cancer. Dietary supplementation with phytoestrogens for chemoprevention of prostate cancer is still a debatable subject. However this is a topic of emerging interest to the general public and to the scientific community due to the possible protective roles of phytoestrogens in chemoprevention and in cancer stabilization. A recent study by Westerlund et al. [81] evaluated patterns of dietary supplement use in men with prostate cancer ( $n=1127$ cases and 900 population controls), and reported that $48 \%$ of individuals with prostate cancer took dietary supplements, a value that was $10 \%$ higher than the prevalence in the population controls. It was also observed that men with healthy dietary pattern are likely to take dietary supplements. Many of the dietary supplementation epidemiologic studies showed an association between high intake of foods rich in phytoestrogens and low incidence of prostate cancer. These associations were based on food frequency questionnaires which can be confounded by recall bias, even though the validity and reproducibility of these questionnaires have been studied [82]. Numerous pre-clinical in vitro studies have been promising, and novel molecular mechanisms of action for phytoestrogens continue to be identified. Given the discovery of multiple molecular targets for phytoestrogen action, the design and use of combination regimens that include other antioxidants, chemopreventive agents or standard therapy provide a promising area of investigation and advancement.

Human clinical trials including studies done on prostate biomarkers and on the effects of phytoestrogens on steroid hormones are complicated by the possibility of local paracrine effects in prostatic tissue by these phytoestrogens that are steroid-like in structure. Their interaction with multiple enzymes represent an interesting paradigm for the complexity of phytoestrogen effects and a window into a potential reason that study results are inconsistent or difficult to explain. Phytoestrogens have been reported to inhibit aromatase, 5- $\alpha$ reductase, $17 \beta$-hydroxysteroid oxidoreductase, and sulfotransferase (SULT) activities [29,37-41]. SULTs, in particular, show complex behaviors with phytoestrogens. They may be induced by phytoestrogens, they metabolize certain phytoestrogens through sulfation, and SULTs are inhibited by phytoestrogens [38,40-41,44]. SULT1A1 (phenol sulfotransferase) and SULT1E1 (estrogen sulfotransferase) are of particular interest in prostate cancer work because they both use estradiol and estrone as substrates, albeit at different concentrations. We have detected SULT1A1 activity in human benign prostatic hypertrophy tissues (Anderson RJ, unpublished observation). Daidzein is an excellent substrate for SULT1A1 at concentrations similar to those measured in prostatic tissue, but higher concentrations of daidzein will inhibit the activity [38]. Genistein serves as a substrate for SULT1E1, and as a potent inhibitor of both SULT1A1 and SULT1E1 at higher genistein concentrations $[38,41]$. In such a milieu, the local concentration of phytoestrogen that finally reaches the prostate likely determines whether it is sulfated and probably deactivated, or whether it induces or inhibits the SULT activities or other enzymes. The final outcome of the phytoestrogen effect in the intact human may be difficult to discern with compounds that can inhibit or induce enzymes, destroy cancer cells, but also will have intrinsic estrogenic effects themselves [37].
Both pre-clinical and clinical studies showed decreases in serum PSA and total testosterone levels with no significant change in free PSA and androgen levels. Based upon the decrease in serum PSA, the antiproliferative effects and growth inhibitory effects of phytoestrogens are biologically plausible mechanisms of action. However, there is not enough evidence to attribute a definitive role for phytoestrogens in the prevention of prostate cancer in high risk males, and the stabilization or chemoprevention of recurrent prostate cancer in patients with this disease.

Safety of phytoestrogens is a concern as no ceiling dose has been defined. Only a few studies have been done to address this concern. For example, the effect on the hypothalamic-pituitary-testosterone axis has been shown to cause compensated hypogonadism [67]. Also, the effect on fertility in males of reproductive age is a rising concern [83]. Kumar et al. [84] did a 12 week randomized, interventional study with daily supplementation of $80 \mathrm{mg}$ of oral purified isoflavone/day versus placebo in men with early prostate cancer $(n=53)$, and reported no clinical toxicity from the drug. However, long term safety data are required before recommendations for standard therapy can be made. Even though human clinical trials have been inconsistent by showing both possible benefits of phytoestrogens, and no protective roles for phytoestrogens in prostate cancer patients, larger randomized trials are needed before accepting or rejecting the hypothesis.

\section{Conclusions}

As discussed above larger multi-center, multi-national randomized control trials are needed before further disposition can be made on the utility of phytoestrogens for prostate cancer chemoprevention and therapy. However, combinations of phytoestrogens with radiation therapy and other antioxidants in advanced or metastatic prostate cancer can be considered as there is a lack of effective therapy options in this group. Results from ongoing clinical trials on these combination studies, especially with calcitriol, are pending. Also, data from the High Risk Prostate Cancer Prevention Study with expected completion in September, 2012 will be helpful (Table 1). Focused pre-clinical studies that clearly define mechanisms of action of phytoestrogens will continue to guide clinical trial design.

\section{References}

1. U.S. Cancer Statistics Working Group (2010) United States Cancer Statistics: 1999-2007 Incidence and Mortality Web-based Report. Atlanta (GA): Department of Health and Human Services, Centers for Disease Control and Prevention, and National Cancer Institute.

2. Breslow N, Chan CW, Dhom G, Drury RA, Franks LM, et al. (1977) Latent carcinoma of prostate at autopsy in seven areas. The International Agency for Research on Cancer, Lyons, France. Int J Cancer 20: 680-688.

3. GLOBOCAN (2008) IARC, Section of Cancer Information.

4. Shimizu H, Ross RK, Bernstein L, Yatani R, Henderson BE, et al. (1991) Cancers of the prostate and breast among Japanese and white immigrants in Los Angeles county. Br J Cancer 63: 963-966.

5. Adlercreutz H (1995) Phytoestrogens epidemiology and a possible role in cancer protection. Environ Health Perspect 10: 103-112.

6. Yildiz F (2005) Phytoestrogens in Functional Foods, CRC, Boca Raton, FL.

7. Basly JP, Lavier MC (2005) Dietary phytoestrogens: potential selective estrogen enzyme modulators? Planta Med 71: 287-294.

8. Messina M, Nagata C, Wu AH (2006) Estimated Asian adult soy protein and isoflavone intakes. Nutr Cancer 55: 1-12.

9. Adlercreutz H (2002) Phyto-oestrogens and cancer. Lancet Oncol 3: 364-373. 
10. Lampe JW (2010) Emerging research on equol and cancer. J Nutr 140: 1369S-1372S.

11. Adlercreutz H (2007) Lignans and human health. Crit Rev Clin Lab Sci 44: 483525.

12. Akaza H, Miyanaga N, Takashima, Naito S, Hirao Y, et al. (2004) Comparisons of percent equol producers between prostate cancer patients and controls: case-controlled studies of isoflavones in Japenese, Korean, American residents. Jpn J Clin Oncol 34: 86-89.

13. Akaza H, Miyanaga N, Takashima, Naito S, Hirao Y, et al. (2002) Is diadzein non-metabolizer a high risk for prostate cancer? A case-controlled study of serum soybean isoflavone concentration. J Clin Oncol 32: 296-300.

14. Park SY, Wilkens LR, Franke AA, Le Marchand L, Kakazu KK, et al. (2009) Urinary phytoestrogen excretion and prostate cancer risk: a nested casecontrol study in the Multiethnic Cohort. Br J Cancer 101: 185-191.

15. Travis RC, Spencer EA, Allen NE, Appleby PN, Roddam AW, et al. (2009) Plasma phyto-oestrogens and prostate cancer in the European Prospective Investigation into Cancer and Nutrition. Br J Cancer 100: 1817-1823.

16. Kilkkinen A, Stumpf K, Pietinen P, Valsta LM, Tapanainen $H$, et al. (2001) Determinants of serum enterolactone concentration. Am J Clin Nutr 73: 10941100.

17. Stattin P, Adlercreutz H, Tenkanen L, Jellum E, Lumme S, et al. (2002) Circulating enterolactone and prostate cancer risk: a Nordic nested casecontrol study. Int J Cancer 99: 124-129.

18. Sonoda T, Nagata Y, Mori M, Miyanaga N, Takashima N, et al. (2004) A casecontrol study of diet and prostate cancer in Japan: Possible protective effect of traditional Japanese diet. Cancer Sci. 95: 238-242.

19. Lee MM, Gomez SL, Chang JS, Wey M, Wang RT, et al. (2003) Soy and isoflavone consumption in relation to prostate cancer risk in China. Cancer Epidemiol Biomarkers Prev 12: 665-668.

20. Kolonel LN, Hankin JH, Whittemore AS, Wu AH, Gallagher RP, et al. (2000) Vegetables, fruits, legumes and prostate cancer: A multiethnic case-contro study. Cancer Epidemiol. Biomarkers Prev 9: 795-804.

21. Jacobsen BK, Knutsen, SF, Fraser GE (1998) Does high soy milk intake reduce prostate cancer incidence? The Adventist Health Study (United States). Cancer Causes Control 9: 553-557.

22. Jian L (2009) Soy, isoflavones and prostate cancer. Mol Nutr Food Res 53: 217-226

23. Ganry O (2005) Phytoestrogens and prostate cancer risk. Prev Med 41: 1-6.

24. Mori M, Masumori N, Fukuta F, Nagata Y, Sonoda T, et al. (2009) Traditional Japanese diet and prostate cancer. Mol Nutr Food Res 53: 191-200.

25. Hedelin M, Klint A, Chang ET, Bellocco R, Johansson JE, et al. (2006) Dietary phytoestrogen, serum enterolactone and risk of prostate cancer: the cancer prostate Sweden study (Sweden). Cancer Causes Control 17: 169-180.

26. Heald CL, Ritchie MR, Bolton-Smith C, Morton MS, Alexander FE (2007) Phyto-estrogens and risk of prostate cancer in Scottish men, Br J Nutr 98: 388396.

27. Taylor CK, Levy RM, Elliott JC, Burnett BP (2009) The effect of genistein aglycone on cancer and cancer risk: a review of in vitro, preclinical, and clinical studies. Nutr Rev 67: 398-415.

28. Banerjee S, Li Y, Wang Z, Sarkar FH (2008) Multi-targeted therapy of cancer by genistein. Cancer Lett 269: 226-242.

29. de Souza PL, Russell PJ, Kearsley JH, Howes LG (2010) Clinical pharmacology of isoflavones and its relevance for potential prevention of prostate cancer. Nutr Rev 68: 542-555

30. Kuiper GG, Lemmen JG, Carlsson B, Corton JC, Safe SH, et al. (1998) Interaction of estrogenic chemicals and phytoestrogens with estrogen receptor beta. Endocrinology 139: 4252-4263.

31. Basak S, Pookot D, Noonan EJ, Dahiya R (2008) Genistein down-regulates androgen receptor by modulating HDAC6-Hsp90 chaperone function. Mol Cancer Ther 7: 3195-3202.
32. Pihlajamaa P, Zhang F, Saarinen L, Mikkonen L, Hautaniemi S, et al. (2011) The phytoestrogen genistein is a tissue-specific androgen receptor modulator. Endocrinology 152: 4395-4405.

33. Davis JN, Kucuk O, Sarkar FH (2002) Expression of prostate-specific antigen is transcriptionally regulated by genistein in prostate cancer cells. Mol Carcinog 34: 91-101.

34. Mousavi Y, Adlercreutz H (1993) Genistein is an effective stimulator of sex hormone-binding globulin production in hepatocarcinoma human liver cancer cells and suppresses proliferation of these cells in culture. Steroids 58: 301 304

35. Hirvonen J, Rajalin AM, Wohlfahrt G, Adlercreutz H, Wähälä K, et al. (2011) Transcriptional activity of estrogen-related receptor y (ERRY) is stimulated by the phytoestrogen equol. J Steroid Biochem Mol Biol 123: 46-57.

36. Molinié B, Georgel P (2009) Genetic and epigenetic regulations of prostate cancer by genistein. Drug News Perspect 22: 247-254.

37. Mäkelä S, Poutanen M, Kostian ML, Lehtimäki N, Strauss L, et al. (2008) Inhibition of 17 beta-hydroxysteroid oxidoreductase by flavonoids in breast and prostate cancer cells. Cancer Epidemiol Biomarkers Prev 12: 665-668.

38. Ebmeier CC, Anderson RJ (2004) Human thyroid phenol sulfotransferase enzymes 1A1 and 1A3: activities in normal and diseased thyroid glands, and inhibition by thyroid hormones and phytoestrogens. J Clin Endocrinol Metab 89 5597-5605.

39. Adlercreutz H, Bannwart C, Wähälä K, Mäkelä T, Brunow G, et al. (1993) Inhibition of human aromatase by mammalian lignans and isoflavonoid phytoestrogens. J Steroid Biochem Mol Biol 44: 147-153.

40. Chen Y, Huang C, Zhou T, Chen G (2008) Genstein induction of human sulfotransferases in Hep G2 and Cac0-2 cells. Basic Clin Pharmacol Toxicol 103: 553-559.

41. Harris RM, Wood DM, Bottomley L, Blagg S, Owen K, et al. (2004) Phytoestrogens are potent inhibitors of estrogen sulfation: implications for breast cancer risk and treatment. J Clin Endocrinol Metab 89: 1779-1787.

42. Luu-The V, Bélanger A, Labrie F (2008) Androgen biosynthetic pathways in the human prostate. Best Pract Res Clin Endocrinol Metab 22: 207-221.

43. Falany CN, Meloche CA, He D, Dumas NA, Frost AR (2004) Expression and subcellular localization of human sulfotransferases (SULTs) in normal and cancerous prostate and breast tissues. Proc Amer Assoc Cancer Res: 45.

44. Nishiyama T, Ogura K, Nakano H, Kaku T, Takahashi E, et al. (2002) Sulfation of environmental estrogens by cytosolic human sulfotransferases. Drug Metab Pharmacokinet 17: 221-228.

45. Fotsis T, Pepper MS, Montesano R, Atkas E, Breit S, et al. (1998) Phytoestrogens and inhibition of angiogenesis. Baillieres Clin Endocrinol Metab 12: 649-666.

46. Swami S, Krishnan AV, Moreno J, Bhattacharyya RS, Gardner C, et al. (2009) Inhibition of prostaglandin synthesis and actions by genistein in human prostate cancer cells and by soy isoflavones in prostate cancer patients. Int $\mathrm{J}$ Cancer 124: $2050-2059$.

47. El Touny LH, Banerjee PP (2007) Akt-GSK-3 pathway as a target in genisteininduced inhibition of TRAMO prostate cancer progression toward a poorly differentiated phenotype. Carcinogenesis 28: 1710-1717.

48. Lakshman M, Xu L, Ananthanarayanan V, Cooper J, Takimoto CH, et al. (2008) Dietary genistein inhibits metastasis of human prostate cancer in mice. Cance Res 68: 2024-2032.

49. Xu L, Ding Y, Catalona WJ, Yang XJ, Anderson WF, et al. (2009) MEK4 function, genistein treatment, and invasion of human prostate cancer cells. $J$ Natl Cancer Inst 101: 1141-1155.

50. Stetler-Stevenson WG, Yu AE (2001) Proteases in invasion: matrix metalloproteinases. Semin Cancer Biol 11: 143-152.

51. Stearns ME, Stearns M (1996) Immunohistochemical studies of activated matrix metalloproteinase-2 (MMP-2a) expression in human prostate cancer. Oncol Res 8: 63-67.

52. Zhou JR, Gugger ET, Tanaka T, Guo Y, Blackburn GL, et al. (1999) Soybean 
phytochemicals inhibit the growth of transplantable human prostate carcinoma and tumor angiogenesis in mice. J Nutr 129: 1628-1635.

53. Fritz WA, Wang J, Eltoum I-E, Lamartiniere CA (2002) Dietary genistein downregulates androgen and estrogen receptor expression in the rate prostate. Mol Cell Endocrinol 186: 89-99.

54. Hong SJ, Kim SI, Kwon SM, Lee JR, Chung BC (2002) Comparative study of concentration of isoflavones and lignans in plasma and prostatic tissues of normal control and benign prostatic tissues of normal control and benign prostatic hyperplasia. Yonsei Med J 43: 236-241.

55. Brössner C, Petritsch K, Fink K, Auprich M, Madersbacher S, et al. (2004) Phytoestrogen tissue levels in benign prostatic hyperplasia and prostate cancer and their association with prostatic diseases. Urology 64: 707-711.

56. Adams KF, Chen C, Newton KM, Potter JD, Lampe JW (2004) Soy isoflavones do not modulate prostate-specific antigen concentrations in older men in a randomized controlled trial. Cancer Epidemiol Biomarkers Prev 13: 644-648.

57. Ward HA, Kuhnle GG (2010) Phytoestrogen consumption and association with breast, prostate and colorectal cancer in EPIC Norfolk. Arch Biochem Biophys 501: 170-175.

58. Dillingham BL, McVeigh BL, Lampe JW, Duncan AM (2005) Soy protein isolates of varying isoflavone content exert minor effects on serum reproductive hormones in healthy young men. J Nutr 135: 584-591.

59. Maskarinec G, Morimoto Y, Hebshi S, Sharma S, Franke AA, et al. (2006) Serum prostate-specific antigen but not testosterone levels decrease in a randomized soy intervention among men. Eur J Clin Nutr 60: 1423-1429.

60. Ide H, Tokiwa S, Sakamaki K, Nishio K, Isotani S, et al. (2010) Combined inhibitory effects of soy isoflavones and curcumin on the production of prostatespecific antigen. Prostate 70: 1127-1133.

61. Kumar NB, Cantor A, Allen K, Riccardi D, Besterman-Dahan K, et al. (2004) The specific role of isoflavones in reducing prostate cancer risk. Prostate 59: 141-147.

62. deVere White RW, Tsodikov A, Stapp EC, Soares SE, Fujii H, et al. (2010) Effects of a high dose, aglycone-rich soy extract on prostate-specific antigen and serum isoflavone concentrations in men with localized prostate cancer. Nutr Cancer 62: 1036-1043.

63. Hamilton-Reeves JM, Rebello SA, Thomas W, Kurzer MS, Slaton JW (2008) Effects of soy protein isolate consumption on prostate cancer biomarkers in men with HGPIN, ASAP, and low-grade prostate cancer. Nutr Cancer 60: 7-13.

64. Hamilton-Reeves JM, Rebello SA, Thomas W, Slaton JW, Kurzer MS (2007) Soy protein isolate increases urinary estrogens and the ratio of 2:16alphahydroxyestrone in men at high risk of prostate cancer. J Nutr 137: 2258-2263.

65. Gardner CD, Oelrich B, Liu JP, Feldman D, Franke AA, et al. (2009) Prostatic soy isoflavone concentrations exceed serum levels after dietary supplementation. Prostate 69: 719-726.

66. Rannikko A, Petas A, Rannikko S, Adlercreutz H (2006) Plasma and prostate phytoestrogen concentrations in prostate cancer patients after oral phytoestogen supplementation. Prostate 66: 82-87.

67. Rannikko A, Petas A, Raivio T, Jänne OA, Rannikko S, et al. (2006) The effects of short-term oral phytoestrogen supplementation on the hypothalamicpituitary-testicular axis in prostate cancer patients. Prostate 66: 1086-1091.

68. Dalais FS, Meliala A, Wattanapenpaiboon N, Frydenberg M, Suter DA, et al. (2004) Effects of a diet rich in phytoestrogens on prostate-specific antigen and sex hormones in men diagnosed with prostate cancer. Urology 64: 510-515.

69. Pendleton JM, Tan WW, Anai S, Chang M, Hou W, et al. (2008) Phase II trial of isoflavone in prostate-specific antigen recurrent prostate cancer after previous local therapy. BMC Cancer 8: 132.

70. Kwan W, Duncan G, Van Patten C, Liu M, Lim J (2010) A phase II trial of a soy beverage for subjects without clinical disease with rising prostate-specific antigen after radical radiation for prostate cancer. Nutr Cancer 62: 198-207.

71. Schröder FH, Roobol MJ, Boevé ER, de Mutsert R, Zuijdgeest-van, et al. (2005) Randomized, double-blind, placebo-controlled crossover study in men with prostate cancer and rising PSA: effectiveness of a dietary supplement. Eur Urol Dec 48: 922-930.

72. Kumar R, Verma V, Jain A, Jain RK, Maikhuri JP, et al. (2011) Synergistic chemoprotective mechanisms of dietary phytoestrogens in a select combination against prostate cancer. J Nutr Biochem 22: 723-731.

73. Vaishampayan U, Hussain M, Banerjee M, Seren S, Sarkar FH, et al. (2007) Lycopene and soy isoflavones in the treatment of prostate cancer. Nutr Cancer 59: $1-7$.

74. Hillman GG, Forman JD, Kucuk O, Yudelev M, Maughan RL, et al. (2001) Genistein potentiates the radiation effect on prostate carcinoma cells. Clin Cancer Res 7: 382-390.

75. Raffoul JJ, Sarkar FH, Hillman GG (2007) Radiosensitization of prostate cancer by soy isoflavones. Curr Cancer Drug Targets 7: 759-765.

76. Ahmad IU, Forman JD, Sarkar FH, Hillman GG, Heath E, et al. (2010) Soy isoflavones in conjunction with radiation therapy in patients with prostate cancer. Nutr Cancer 62: 996-1000.

77. Krishnan AV, Swami S, Moreno J, Bhattacharyya RB, Peehl DM, et al. (2007) Potentiation of the growth-inhibitory effects of vitamin $D$ in prostate cancer by genistein. Nutr Rev 65: S121-S123.

78. Kumi-Diaka J, Merchant K, Haces A, Hormann V, Johnson M (2010) Genisteinselenium combination induces growth arrest in prostate cancer cells. J Med Food 13: 842-850.

79. Zhao R, Xiang N, Domann FE, Zhong W (2009) Effects of selenite and genistein on G2/M cell cycle arrest and apoptosis in human prostate cancer cells. Nutr Cancer 61: 397-407.

80. Chang KL, Cheng HL, Huang LW, Hsieh BS, Hu YC, et al. (2009) Combined effects of terazosin and genistein on a metastatic, hormone-independent human prostate cancer cell line. Cancer Lett 276: 14-20.

81. Westerlund A, Steineck G, Bälter K, Stattin P, Grönberg H, et al. (2011) Dietary supplement use patterns in men with prostate cancer: the Cancer Prostate Sweden study. Ann Oncol 22: 967-972.

82. Yamamoto S, Sobue T, Sasaki S, Kobayashi M, Arai Y, et al. (2001) Validity and reproducibility of a self-administered food-frequency questionnaire to assess isoflavone intake in a japanese population in comparison with dietary records and blood and urine isoflavones. J Nutr 131: 2741-2747.

83. West MC (2007) The impact of dietary oestrogens on male and female fertility Curr Opin Obstet Gynecol 19: 215-221.

84. Kumar NB, Krischer JP, Allen K, Riccardi D, Besterman-Dahan K, et al. (2007) Safety of purified isoflavones in men with clinically localized prostate cancer. Nutr Cancer 59: 169-175. 